\title{
Public Space as Contested Space: The Battle over the Use, Meaning and Function of Public Space
}

\author{
Rowena Capulong Reyes
}

\begin{abstract}
Background: The optimists among the public space scholarship argue that instead of a well-organized, carefully concerted and highly controlled urban social life, what unfolds in regulated public spaces are a mélange of manifold incongruous lifestyles and a spatial condition. Thistheoretical proposition claims that public spaces are contested spaces offering a potent description of everyday reality in privatized public spaces like the shopping mall. But is a similar mechanics available outside the developed world? Objective: The study looked into the empirical validity of the urban spatial experiences of a developing country like the Philippines. Method: Case study method is employed. Verbal and observational data were analyzed using the process of pattern matching. Findings: Evidence indicates that oppositional politics exists in the public spaces of the privatized built environments. And this oppositional politics springs from three competing conceptualizations: the "by us", "for us", and "up to us" mentalities. Lessons Learned: Public space is not just about regulation; it is also about opposition. But unlike traditional forms of oppositional politics, these are not organized conquest of mall spaces; instead, they simply are individual acts of passive defiance.
\end{abstract}

Index Terms-Public space, oppositional politics, social control.

\section{INTRODUCTION}

Critical scholars of urban geography and sociology describe the contemporary urban social order as hollowed out and denied of genuine public life [1]-[4]. They ascribe this to the sharp decline of democratic public spaces brought about by the phenomenal rise of highly regulated private built environments like the modern shopping malls. The argument is that these privately-managed built environments do not embody a public space which, in the words of Habermas [5], is "the sphere of private people come together as a public" (1993: 27), but a highly restrictive, manipulated public space accessible only to those who can pay and governed by their private owner's hegemonic vision of social order - one which glorifies consumption and homogenous lifestyle - through the deployment of architectural and martial techniques of social control [1], [6]-[9].

This explanatory framework is powerful as it is useful. One reason is that it reveals the power dimensions of public spaces. Far from being neutral, public spaces can be as equally potent in promoting an exclusionary order as in embodying a particular set of social values [10]-[12]. The

Manuscript received September 19, 2014; revised November 18, 2014. Rowena Capulong Reyes is with Far Eastern University, Philippines (e-mail: rcreyes@feu.edu.ph). other reason is corollary to the former: It makes one aware not only of how public spaces regulate human behavior but also how they constitute individual identity [13]. Yet still, the critical scholarship describes an insufficiently comprehensive picture of the complicated realities of everyday life in contemporary public spaces. This is because it fails to take into account the inherent ability of human beings to interpret and reconstruct spatial realities in the light of their own social experience and in ways that best suit their own needs.

Indeed, spatial authorities employ strategies to "put order on things" or in the words of de Certeau [14] "transform the uncertainties into readable spaces." However, in response, users of public spaces adopt their own "tactics" which, on the contrary, intends to delineate a "space full of openness without social and economic constraints" in which to act out their daily survival routines [15]. Thus, instead of a wellorganized, carefully concerted and highly controlled urban social life, what unfolds in public spaces are a mélange of manifold incongruous lifestyles and a spatial condition that is invariably open to what Sennett [16] describes as "constant alteration." Public spaces then are contested spaces: an arena of struggle for social control - the authority to impose what is and what is properly public between, on one side, the private managers and, on the other, the public users.

The proposition is promising especially since the urban spatial realities of western countries lend empirical support to it. But is a similar mechanics available outside the developed world? The purpose of this study is to establish whether the urban spatial realities of a developing country like the Philippines is characterized really by contestations over the meaning and purpose of public space. To elucidate on the matter, it describes and examines the disparate visions or mentalities about public spaces persisting in selected Philippine shopping malls and how their interface conditions the everyday realities of spatial life in these regulated built environments.

\section{METHOD}

This research undertaking uses multiple case study method. To sufficiently describe the contested nature of public spaces of the shopping mall, this researcher deployed various data gathering techniques like field observations and interview. The study chose three shopping malls as sites of its research, namely: Robinson's Place in Ermita, Harrison Plaza in Vito Cruz, and Tutuban Center in Divisoria, all in the city of Manila. These malls cater to different socioeconomic sections of the population and thus represent different types of "public" and diverse responses 
to spatial control and restriction practices. Thirteen (13) individuals consisting of four (4) mall managers and nine (9) mallusers from three Manila shopping malls were tapped as respondents for this study.

\section{A. Data Collection and Ethical Consideration}

Verbal and observational data serve as basis in clarifying what Mitchell [8]calls "the dialectical negotiation" between mall management and mall users for the construction of the daily socio-spatial order inside the shopping malls. To gather data and information, the researcher conducted a two-fold strategy. The first one involved what Merton, Fiske, \& Kendall [17], calls focused interview. During the interview, questions were designed to encourage respondents to express freely their insights and for the interview sessions to assume a conversational manner. For Kvale[18], such mode of interview allows the researcher a greater chance to capture, understand and interpret not only experiential data but also the context of the experience itself.

The second one involved taking photographs and video recording. The researcher took notes and mapped the pertinent activities using video camera to register the evidences of those activities. Over the period of three months, the researcher spent long hours of observation (during working days and weekends from the opening of the establishment, $10 \mathrm{am}$, till closing, $10 \mathrm{pm}$ ) to witness, document, and examine the behavior of mall users. In some instances, the researcher participated in the social activities of mall users, e.g., dining, strolling, etc. to get a feel of the situation. Participation was meant to facilitate a good cross comparison of uses of public spaces and behaviors of mall users and also, to borrow from Snow and Morrill [19], to secure "a close approximation of the empirical world", in this case, the responses to spatial regulations and the playing out of social life inside the shopping malls.

For the interview, first, the researcher asked the permission of the intended participants. The researcher duly informed the respondents that conversations were audio and video recorded for documentation and analysis purposes.

\section{B. Mode of Analysis}

Discovery of themes is imperative in the analysis of qualitative data. As Ryan and Bernard [20] explain, "[w] without thematic categories, investigators have nothing to describe, nothing to compare and nothing to explain."For this study, theme identification was carried out by first transcribing the recorded interviews, expressions, and observational data into field text. Transcriptions were then carefully scrutinized. Following Borgdan and Taylor cited in [20] "topics that occur and reoccur" were classified as thematic categories. The identified themes became the basis for describing the contested nature of spatial realities in the aforementioned malls. Descriptions of spatial condition in one shopping mall were then examined in comparison to those of the other two shopping malls using pattern matching.

\section{Theoretical Framework}

To shed light on its research concern, this study anchors its investigation on the theoretical propositions of De Certeau[14]. Both scholars of public space emphasize the causal function of human agency in spatial order. De
Certeau [14] argues that individuals and groups "caught in the web of the discipline of urban planning," can actually evade the social control of architectural manipulations and become "poets of their own acts" through "tactics" involving timing and insinuation. He defines tactics as a form of response to spatial regulation which is not oppositional in the traditional sense. It is rather a way of acting that gains its efficacy from the proper use of time: "A tactic insinuates itself into the other's place, fragmentarily, without taking it over in its entirety, without being able to keep it at a distance... because it does not have a place. A tactic depends on time - it is always on the watch for opportunities that must be seized "on the wing"' (1984: xix). For De Certeau [14] acting "out of place" at the right time in public spaces are the most common ways how people embrace public spaces as their own and alter their use, meanings, and functions.

Public space therefore is not just a locus of dominance wherein the few powerful define the rules of the game for the sake of maintaining a social order servile to their interests while users are expected to sheepishly accept impositions in recognition of their "proper" roles in this spatial reality. In fact, it is more a contested than a regulated space where users, too, in their own ingenious means try to manage the conduct of their own spatial activities. At stake in these contestations is whose values or symbolic meaning should determine the proper function of public spaces and accordingly define what aptly constitutes public behavior and activities.

Often, the contests for space manifest through the users' defiance of spatial regulations. During these occasions, people seek opportunities to oppose impositions and endeavor to appropriate spaces for their own exclusive use and enjoyment. Defiance occurs because humans as users of public spaces do not simply act; with their social experience mediating, they create and attach meaning to each of their action. This makes an act of defiance to spatial regulations by someone who access space an act of symbolic reconstruction of public space [21]. Through "acting out of place", mall users generate occasions for theconscious redefinition and re-territorialization of public space.

Ironically, the contested nature of public spaces - the most common and the single most important feature of contemporary urban spatial reality - is taken for granted. This perhaps could be the chief reason behind the lack of analytical attention to the simple, daily reactions of people to spatial rules. But it is in fact in these seemingly meaningless snippets of life unfolding in public spaces a more insightful vision of the social and the political could be mined. A close attention therefore to these taken-forgranted details would expand the purview of the political and the social to include what is commonly perceived as non-political and non-social [22].

\section{FINDINGS}

What constitutes appropriate behavior and therefore must be displayed in public spaces depends on what the "public" in public spaces means. Analyses of the field text involved in this particular study yielded three distinct mentalities in conceiving public spaces: the "by us", "for us", and "up to 
us" mentalities. The contestations between these mentalities constitute the everyday spatial life inside themalls under investigation.

\section{A. “By Us” Mentality}

In the eyes of the mall managers, the shopping mall performs a public function: providing safe and comfortable area for consumption and leisure. Yet because it is owned and operated under private hands, the mall management possesses all the right in the world to impose its vision of order, that is, promote spatial regulations it deems fit to maintain a spatial condition conducive to consumer activities. This includes of course deployment of control techniques meant to discipline, deter, and discriminate the behavior of mall users. In other words the meaning and function of the mall spaces along with the legitimate claim to determine what conduct or identity should be paraded or displayed on them solely rests on the discretion of the private management. This "by us" mentality, from the point of view of mall management, should be the basis of spatial life inside the privatized public spaces of the shopping mall. This sentiment is verbalized by the mall managers:

\section{B. "For Us" Mentality}

Some mallusers, on the other hand, conceive the privatized public spaces of the shopping mall as an arena for the expression of individual freedom. Based on this interpretation, mall spaces should be used for whatever purpose which the mall-user thinks fits her needs and preferences without restrictions or constraints. As a public place, mall premises are open to everyone, consumer or not, provided that she does and will not deny other mall-users of their opportunities to enjoy the same rights and entitlements. Public spaces are meant "for us" and therefore should be used for the full satisfaction of the users.

Often, people who conceive public spaces this way are those who profess strong sense of civic virtue.

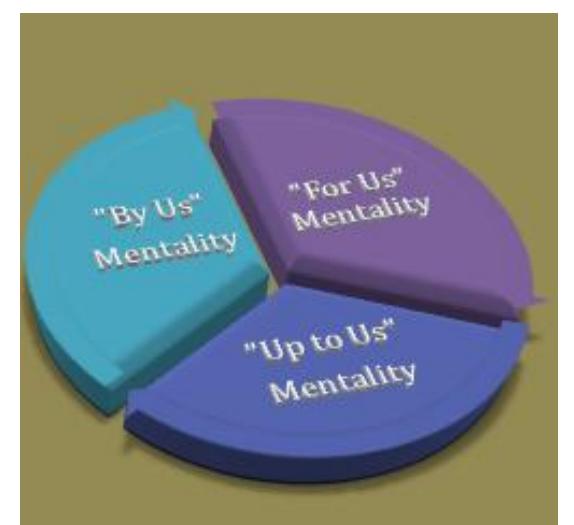

Fig. 1. The three distinct mentalities the contest of which constitutes the spatial reality of the three Manila shopping malls.

\section{C. “Up to Us” Mentality}

But there are conceptualizations in which the meaning of appropriate behavior is derived not from a conception of the proper function of public space but on the timing of a specific conduct or activity. This mentality admits that the mall management has the power and right to define what kinds of activities should be allowed within mall premises, given their private proprietorship over the place. Be that as it may, some mallusers try to evade the prying eyes of mall security and venture into something which they know are restricted inside the mall premises. The act is assumed to be appropriate as long as it is not seen or noticed by security personnel. Conversely, the act becomes inappropriate when discovered and busted. Thus, it is "up to us", as they say, to manipulate the space and find the perfect timing to operate behind the back of the mall security (see Fig. 1).

\section{DISCUSSION}

Based on the findings of this study,oppositional politics exists in the public spaces of the privatized built environments. And this oppositional politics springs from the competing interpretations of the protagonists regarding the proper meaning and function of public spaces. On one side is the mall management which, through its control "strategies", produces a space which serves as, in the words of Mitchell [9], "a controlled and orderly retreat where a properly behaved public might experience the spectacle of the city" (emphasis in the original). On the other side are the mall-users whose views regarding public spaces transform the mall into an arena of politically and socially unconstrained human interaction. It is inevitable for these two worldviews to clash considering the diametrically opposed values they embody: order versus freedom, uniformity versus diversity.

But what is the nature of these contestations? From the standpoint of the mall management, as private proprietors of mall spaces, it is within the purview of their legal and formal rights to utilize the place for whatever end and prescribe a specific form of socio-spatial order supportive of that end. That the rules of propriety within the shopping mall should be defined "by us" alone and not by somebody else, is a management principle strictly observed by the private managers. This "by us" mentality is justified by political economic considerations. As a built environment for consumption, it is imperative for the shopping mall to keep business and profit up to stay competitive. Profitability in the perspective of the mall managers depends on the good management of mall spaces, meaning, and the efficiency of mall spaces to host luxurious lifestyle, tourism, and retail operations. Thus spatial control has to be strictly upheld to enforce what in the management's view is appropriate standard of behavior. In pursuit of this, an array of control techniques is deployed, purposively, to discipline mall-users into acting "in-place", deter "out-of-place" conduct or disruptive activities, and discriminate or exclude potential causes and sources of trouble.

Yet in the course of securing its political economic agenda, as Foucauldian [23] scholarships point out, the 'by us" mentality of the mall management systematically erodes the associational sphere. Overemphasis on spatial order represses individuality of mall-users along with their opportunities to realize personal self-fulfillment through social interaction in open and free spaces. Because of this, the private mall manager is no different from Fishman's [24]"arrogant" and "undemocratic" planner who "only fills his city with his buildings, his sense of proportion and color; and most profound, his social values."

Evidence from the three malls suggests that the "by us" mentality of the mall management does not always solicit full compliance from the mall users. In fact, the mall users 
respond differently. Two oppositional mentalities emerge in response to the former. One of these oppositional attitudes is represented in this study as the "for us" mentality. The "for us" mentality puts less emphasis on the socioeconomic identity of the mall-user - the customer - and more on her sociopolitical identity - the citizen - along with the civic and political endowments the law guarantees to her. As such, instead of adopting the values of the "by us" conception of public space-efficiency-the "for us" conception of public space promotes the virtue of democratic inclusivity.

From the "for us" vantage point, public spaces are meant for the unbridled display of individuality as well as tolerance for diversity. The fact that the public space provides physical and geographical context for many a social function, though privately owned, still, as a paying customer, everyone has the right to use it for her own advantage. Being a participant in a commercial transaction, the mall-user expects to get what in her point of view is justly owed to her - satisfaction - and this includes enjoying the place without unnecessary interference. Such user-centered thinking, accordingly, empowers and justifies an "appropriation" of space, albeit, symbolic, by mall-users for 'public' purposes, that is, support human interaction and social encounter in whatever way possible. In this case, a "for us" mentality treats mall-users as subjects, and their object is their own open space in which they can live according to their own rules and standards.

Naturally, the "for us" mentality of the mall-users puts them on a collision course with the mall management and its imperious "by us" mentality. Yet the oppositional relationship between them does not redound to a face-toface match for control [25]. The reason for this is the calculated refusal of mall-users themselves to engage in the traditional oppositional politics of "war of position."

A war of position entails a direct attack against a declared enemy in order to take over a territorially bounded entity. Obviously, such kind of opposition will not work well for mall-users who, in the first place, neither legally owns the space nor has the means to directly confront the private security system of the mall.

Thus, instead, the "for us" crowd among the mall-users for practical reasons designs ways and looks for occasions to manipulate spaces and oppose the intentions of spatial governance while at the same time exploit the prospects mall spaces offer for personal or collective satisfaction and survival. The goal then is never to win against the dominant forces within mall spaces, but simply not to lose; not to physically own the space, only to metaphorically claim them [25], [26]. In this kind of mentality, opposition is also intended to be noticed largely to annoy the representations of authority. Creswell [26] calls this oppositional attitude "transgression."

The other oppositional mentality is referred to as "up to us" mentality. The "up to us" mentality of oppositional politics, like the "for us" mentality, seeks to insinuate themselves in the space "of the other", the mall management, in order to access it and exploit it for their own ends. Yet, not like the "for us" oppositional mentality, "up to us" mentality refrains from making its "tactics" known to the spatial regulators. They adopt the "guerilla tactic" because, in themselves, they admit that their spatial activities are "out of place". Nonetheless, rational in their calculations, they pursue them anyway knowing that the benefits far more outweigh the costs. It is "up to us", so they say, if they were caught or not. The "up to us" oppositional attitude, in other words, involves risk-taking and thus relies heavily on stealth; they invariably keep a low profile, lest they want their "guerilla operation" exposed and thereby permanently removed.

For this mentality, what is public space and what are the types of conduct and activities that should be displayed on it is mediated by the user's own mode of survival. This fits Creswell's [26] description of "resistance". Resistance, he explains, "occurs behind the backs of those who are being resisted" (1996: 23). This is different with what he calls "transgression" - the "for us" mentality - which rests on being noticed by those they are resisting - the agents of "by us" mentality.

\section{A. The Case of Robinson's Place}

Among the three shopping malls analyzed in this study, Robinson's Place demonstrates the highest degree of spatial regulation and therefore social control. With a clientele of more than 250,000 each day, Robinson's Place deploys a good number of security guards to secure its premises. Though the manager did not state the exact figure, judging by their security assignments, it is safe to say that the private security force of the mall is strong enough to satisfy its sophisticated security requirements. Beside those guards assigned to watch over stores and mall properties, additional security personnel patrol around to monitor the movement and activities of mall users in different strategic locations. As an added security feature, the mall has its own canine unit. In addition, plainclothes security agents are deployed to blend in the crowd to do monitoring and surveillance functions. With its capable security force, the mall management is able to implement its own interpretation of what constitutes appropriate activities and behavior inside the mall.

Be that as it may, still, this "by us" mentality of the mall management faces constant challenge from equally purposive mall users. Considering the extensive reach of the mall's security forces, the mall management is expected to achieve total control over the use of including the movement of people within the shopping spaces. Yet in several areas of the mall, particularly in common areas like the food court, it appears that a different mentality persists alongside that of the dominant forces of the mall. During one field observation, a particularly interesting incident was witnessed by this researcher. In the food court, a group of humorous young people was rudely interrupted in their meal by a security guard for being noisy. The guard instructed the group to keep the tone of their voices low. In response, after the guard had walked a few steps away from their table, the group burst into sarcastic laughter in an act of defiance and to annoy the guard. Such an event demonstrate that though the mall is a private property and that the "by us" mentality of the mall management is supposed to dominate, still, mall users, thinking that they are paying customers, use the mall spaces in the light not of the mall regulations but of their own agenda. This proves 
that even in a highly regulated shopping mall like Robinson's the "by us" mentality of purposive mall managers is far from hegemonic and that some equally purposive mall users can set an alternative culture without resorting to a confrontational and literal "take over" of the mall.

Surprisingly, even in a shopping mall with strong "by us" mentality, defiance to spatial regulations occurs in a daily basis. Even more surprising, some forms of defiance go unnoticed by security personnel.For instance, in one of this researcher's field visits, she met a group of real estate agents doing their daily grind of marketing condominium units to interested mall users. The business has no permit from the mall management and therefore is not allowed to operate inside. Yet for quite some time they have succeeded in evading the strict spatial rules of the mall and actually generate a handsome income. One of the group members explain that key to their survival is timing and calculation: they operate only on areas not frequented by the guards or when security guards are not around. This behavior is a fine example of an "up to us" mentality towards public space. For these purposive mall users, there is an explicit recognition that what they are doing is "out of place". But they keep on doing it in view of the potential personal benefits they can derive from such defiance. Accordingly, these mall users resort to ingenious strategies to minimize the chances of being caught.

\section{B. The Case of Tutuban Center}

Just like Robinson's Place, Tutuban Center uses spatial control techniques to maintain order within the mall premises. Through these techniques, the mall is able to carry out its vision of what a public space should be. The most obvious of these techniques through which the mall management's "by us" mentality is expressed is the deployment of private security forces.

From the perspective of the managers, as its operators, they have exclusive authority over the mall spaces of Tutuban Center. They have the sole power to design its spatial regulations and specifically to admit and bar people from entering the mall premises. For instance, security personnel are constantly on the watch out for the unkempt, elderly beggars, and sex workers who manage to evade security checks and use the spaces of the mall for activities which, in the eyes of the management, are completely inappropriate inside the mall.

Just like in Robinson's, in Tutuban, the mall management is not the only purposive actor which is actively imposing meaning and interpreting the proper function of public space. There are mall users as well who think that Tutuban, as a commercial center where paying customers could spend their money, is theirs to access and use. Again, just like in Robinson's, common areas like the food court open possibilities for the "for us" mentality of mall users to be expressed. In this particular area of the mall, people are often seen "taking over" the place and doing what they think is appropriate in a public space like the food court. For instance, during her field observations, this researcher noticed that several people taking their lunch in the food court do not eat food bought from the nearby stalls. They have their own food with them. They enjoy eating there because the place is air-conditioned. When asked, one of them explained that there is nothing wrong with their behavior since they already bought something from the mall, e.g., a bottle of water or soda. By virtue of that purchase, they are entitled to use all the amenities of the mall.

"Up to us" mentality also thrives in certain parts of Tutu ban. Tutu ban Center caters to more than 100,000 clients every day. With that sheer number of people it is understandable why sometimes security become lax. During these moments certain people are able to access the spaces of the mall and do certain things which are not normally allowed. As observed by this researcher, and confirmed by the chief security officer of the mall in an interview, this "incursion" regularly happens. Often, old beggars take advantage of the openings. They usually roam around the computer arcade and beg for alms and look for leftover food in the food court. Sometimes, as the security officer himself admitted, security guards find it difficult to arrest cases like these because the beggars employ guerilla tactics. They use stealth to escape the prying eyes of the security personnel. Sometimes security personnel get frustrated that they deliberately ignore some of these activities.

\section{The Case of Harrison Plaza}

Among the three shopping malls Harrison Plaza has the lowest degree of spatial government and thus has the weakest level of social control. But this does not mean that the management has no vision of spatial order. The mall management knows exactly what it needs to do, what are the significance of the spatial rules and what their implications are to the commercial activities inside the mall premises. But it lacks the capacity to carry out the will or to translate the vision into a concrete spatial order. As explained by the mall manager, the financial, managerial and logistical limitations of the mall keep the mall from being managed professionally.

The weak "by us" mentality of Harrison's management has appositive implication tithe "for us" mentality of purposive mall users- most of them are residents of nearby informal communities. These mall users overwhelm the mall spaces, "appropriated" them and imposed their own rules and version of order as though it was their "own" personal space. For instance, one time when this researcher conducted direct observation inside the mall, she saw a disheveled mother sitting on one of the benches in the lobby. Unmindful of the place, she pulled her shirt up and breastfed her baby as though she was in her own house. Another interesting scene was the crowd of by-standers gathered in front of an appliance store to watch a full-length movie being played in one of the television sets on display as if they were in front of their own television set and sitting on the couch of their own living room. Also, in some areas, beggars loiter around begging and picking up left-over food in trash bins. Some even walk around the wide alleys in tattered clothes plastic bags full of throw-away things in their hands.

These behaviors and activities are the very things spatial govern mentality intends to displace and exclude from public spaces. One cannot expect to see such expressions of incivility and lack of urbanity in shopping malls exercising high levels of spatial regulation like Robinson's and Tutu 
ban. In the case of Harrison Plaza, the inability of the mall management to enact its own vision of order ("by us" mentality) in effect abetted purposive mall users to colonize mall spaces and define spatial order based on their own vision of order ("for us" mentality).

But this is not to say that the mall management practically has no power or control over its own spaces. In fact, notwithstanding the weakness of spatial govern mentality, still, the management is able to implement the most basic of spatial rules and maintain a modicum of order in certain spaces of the mall. For example, it imposes regulations as regards the use of restrooms and other common areas like the food court. Nonetheless, even in these relatively regulated areas, the spatial rules are bent by purposive mall users to satisfy their interests. In some cases, as the mall manager himself revealed, these acts of defiance were accomplished with the connivance of some security and mall personnel themselves. For example, some residents of nearby informal settlements frequently use the mall's restrooms as their own bathrooms. Sometimes they use these facilities for free but more often by bribing the security guard or the janitor assign there. In this specific instance, the "up to us" mentality of some purposive mall users upset the efforts of the mall management to establish its rules without being confrontational using only stealth and cooptation techniques.

\section{LESSONS LEARNED}

By examining the nature ofoppositional relationship between the contending purposive actors - the managers and the users - inside the shopping mall, this paper reveals how the different and invariably contradictory mentalities operating in mall spaces construct the spatial reality of contemporary urban spaces. Contrary to the claims of critical scholars, spatial regulations elicit pockets of responses which tend to affirm not the social control of mall management but the agency of mall-users. This agency is pronounced in the mall-users' personal expressions of opposition to the management's vision of order. But unlike traditional forms of oppositional politics, these are not organized conquest of mall spaces; instead, they simply are individual acts of passive defiance. Yet in the course of playing them out, mall-users redefine the meaning and purpose of mall spaces, and accordingly, sanction multiple interpretations of appropriate behavior in public.

Expressions of resistance to spatial regulations- which from the perspective of mall management is just but disorderly conductsthat needs to be removed in public sight - is a testimony to the brimmingpotentials of public spaces to host a vibrant associational life. By zooming in on these daily, albeit, taken-for-granted personal responses, inevitably, one can find a fertile ground for discussions on postmodern conceptions of the political and the social. These spatial realities or what De Certeau [14] refers to as "art of everyday life", which contrary to traditional conceptions of politics and society, is as political and as social as the usual units of authority and association at the macro level. Analyzing them inspires an expansion in terms of the meaning of the political and the social. This brings significant implications both to scholarships of urban space and public policy as they bring to the fore issues which are normally considered as apolitical and therefore are shut out in public discussions.

It is beyond the concern of this paper to discuss issues and challenges in urban planning. However, scholars of urban planning and design need to heed growing calls for them to respect the daily lifestyle of public space-users [27]-[29]. The focus of spatial plans and designs must consider first and foremost the user, her needs, and how they can be satisfied. As for local policymakers, they have to promote policies and pursue programs which facilitate user-oriented public spaces. In particular, they have to invest more resources in developing ways to encourage the participation of users in designing open environments that suit their associational needs. Unfortunately, there exists a dearth in user-oriented approaches to design and even spatial governance [25]. This is something which future research has to address.

\section{REFERENCES}

[1] M. Sorkin, Variations on a Theme Park: The New American City and the End of Public Space, New York: Hill and Wang, 1992.

[2] N. Rose, Governing the Soul: The Shaping of the Private Self, London: Routledge, 1992.

[3] S. Flusty, "Building paranoia," in A rchitecture of Fear, N. Ellin, Ed. New Jersey: Princeton Architectural Press, 1997, pp. 47-60.

[4] M. Castells, "the space of flows" in The Castells Reader on Cities and Social Theory, I. Susser, Ed. NJ: Blackwell, 2001, pp. 314-366.

[5] J. Habermas, The Structural Transformation of the Public Sphere, Cambridge: MIT Press, 1993.

[6] E. Sorja, Postmodern Geographies: The Reassertion of Space in Critical Social Theory, London: Verso, 1989.

[7] M. Crawford, "Contesting the public realm: Struggles over public space in Los Angeles," Journal of Architectural Education, vol. 49, no. 1, pp. 4-9, 1992.

[8] M. Davis, "Fortress Los Angeles: The militarization of urban space," Variations on a Theme Park: The New American City and the end of Public Space, New York: Hill and Wang, 1992, pp. 154-180.

[9] D. Mitchell, "The end of public space? people's park, definitions of the public, and democracy," Annals of the Association of American Geographers, vol. 85, no. 1, pp. 108-33, 1992.

[10] S. Davis, Parades and power: Street the Atre in NineteenthCentury, Philadelphia: Temple University Press Philadelphia, 1986.

[11] S. Merry, "Spatial govern mentality and the new urban social order: Controlling gender violence through the law," American Anthropologist, vol. 103, no. 1, pp. 16-29, 2001.

[12] D. Mitchell and L. Staeheli, "Locating the public in research and practice," Progress in Human Geography, vol. 31, no. 6, pp. 792-811, 2007.

[13] S. Clegg, D. Courpasson, and N. Phillips, Power and Organizations, London: Sage, 2006.

[14] M. D. Certeau, The Practice of Everyday Life, Los Angeles, CA: University of California Press, 1984.

[15] K. Lynch, "The openness of open space," Citysense and City Design: Writings and projects of Kevin Lynch, The MIT Press, 1990, pp. 396413.

[16] R. Sennett, The Uses of Disorder: Personal Identity and City life, New York: W. W. Norton, 1970.

[17] R. Merton, L. Fiske, and P. Kendall, The Focused Interview: A Manual of Problems and Procedures, New York: The Free Press, 1990.

[18] S. Kvale, Interviews: An Introduction to Qualitative Research Interviewing, California: Sage Publications, 1996.

[19] D. Snow and C. Morrill, "Reflections on anthropology's ethnographic crisis of faith," Contemporary Sociology, vol. 32, pp. 8$11,1993$.

[20] G. Ryanand and H. Bernard, "Techniques to identify themes," Field Methods, vol. 15, no. 1, pp. 85-103, 2003.

[21] S. Low, "Spatializing culture: The social production and social construction of public space in costa rica," American Ethnologist, vol. 23, no. 4, pp. 861-879, 1996.

[22] P. Mann, Micro-Politics: Agency in a Post-feminist Era, Minneapolis: University of Minneapolis Press, 1994. 
[23] M. Foucault, "Governmentality," The Foucault Effect: Studies in Governmentality, University of Chicago Press, 2008, pp. 87-104.

[24] R. Fishman, Urban Utopias in the Twentieth Century: Ebenezer Howard, Frank Lloyd Wright, and Le Corbusier, Cambridge, MA: The MIT Press, 1982.

[25] K. W. Siu, "Guerrilla wars in everyday public spaces: Reflections and inspirations for designers," International Journal of Design, vol. 1 , no. 1, pp. 27-36, 2007 .

[26] T. Creswell, In Place/Out of Place: Geography, Ideology, and Transgression, Minneapolis: University of Minneapolis Press, 1996.

[27] H. Sanoff, Integrating Programming, Evaluation and Participation in Design: A Theory Zapproach, Hants: Ashgate, 1992.

[28] H. Sanoff, Community Participation Methods in Design and Planning, New York: John Wiley and Sons, 2000.

[29] D. Schuler, Participatory Design: Principles and Practices, Hillsdale, NJ: L. Erlbaum Associates, 1993.

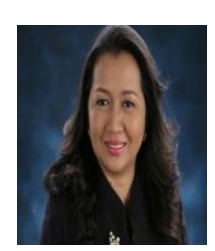

Rowena Capulong Reyes is the manager for marketing and communication of the Far Eastern University. Dr. Reyes' research interests cover spatial governance, associational life and communication studies. She received her BA in communication arts from the University of Sto. Tomas, she received her MA in communication management from the Asian Institute of Journalism and Communication and she received her $\mathrm{PhD}$. in development studies from the University of Sto.Tomas.

As an accredited PR counselor, she is a partner and managing director of 5BC Integrated Marketing Communication. She is the PRO of the Philippine Association of Communication Educators, Inc., and was past president of the Public Relations Educators Association of the Philippines. 